\title{
The influence of grain-beet crop rotation with different leguminous predecessors of winter wheat on the nutritive regime of typical chernozem
}

\author{
S. Kudria \\ Kharkiv National Agrarian University named after V.V. Dokuchaev \\ p.o. Dokuchaievske-2, Kharkiv region, Kharkiv oblast, 62483, Ukraine \\ e-mail: KudryaSI.com@gmail.com \\ ORCID: 0000-0002-4581-8426
}

Goal. To investigate the nutritive regime of typical chernozem in short grain-beet crop rotation with different legumes predecessors of winter wheat. Methods. General scientific and special. Agrochemical analyses were performed according to standard techniques. Results. The security of soil with easily hydrolyzing nitrogen for 11 rotations of 4 -fields crop rotation did not depend on the predecessor of winter wheat and made $112-120 \mathrm{mg} / \mathrm{kg}$ of soil. There was a tendency to increase its content in the crop rotations with legumes predecessors of winter wheat. On average over the 14 years of research, the amount of mobile phosphorus in the topsoil was $122-137 \mathrm{mg} / \mathrm{kg}$ of soil. The highest content was in crop rotations with bare fallow - $137 \mathrm{mg} / \mathrm{kg}$ and fallow under vetch-oats mixture $-131 \mathrm{mg} / \mathrm{kg}$ soil. They observed an increase in exchange potassium content in the arable layer of soil in crop rotation with bare fallow. Its amount in the soil on average, before the harvest of barley, was greater on $14 \mathrm{mg} / \mathrm{kg}$ of soil than after other predecessors. In varients with legumes predecessors and corn for silage, they received the equal results $-115-119 \mathrm{mg} / \mathrm{kg}$ of soil. Conclusions. Compared to baseline data obtained during the laying of the experiment, research results for the period 1996-2009 had shown that prolonged use of short crop rotation improved the soil supply with nitrogen and phosphorus. On the contrary, the concentrations of these elements in the topsoil, the quantity of exchangeable potassium during this period had decreased. Most secured with phosphorus and potassium were crop rotation with bare fallow, with nitrogen and phosphorus - crop rotation with the vetch-oats mixture. Crop rotation with leguminous predecessors had the best ratio of nitrogen than that of crop rotation with bare fallow and corn silage.

Key words: crop rotation, soil, nitrogen, phosphorus, potassium.

DOI: https://doi.org/10.31073/agrovisnyk202004-02

One of the most important task in the field of agriculture is the rational use of land as the main means of production in agriculture and the transformation of the natural soil-creating process into a targeted "cultural" process, which provides improved soil fertility and, on this basis, increased crop yields. The recognition of the laws of the modern cultural soil-producing process allows us to predict the direction of its development, rationally use the soil and plan measures to ensure continuous improvement of its effective fertility and high yields.

There are many reports on the effects of plant soil, fertilizers and cultivation that highlight only some issues related to such action [1-8]. In addition, these scientific data were obtained in different soil and climatic zones, which makes it impossible to draw any conclusions regarding the change of fertility of the chernozem in the eastern region of Ukraine. Many researchers have devoted their scientific works to the study of changes in soil fertility under the influence of crops [9-13]. This data also contains opposite views.

The purpose of the study is to identify the course of change of agrochemical indicators of fertility of typical chernozem of 11 four-field rotations.

Materials and methods of research. The studies were conducted on the experimental field of Kharkiv National Agrarian University named after V. V. Dokuchaev during 1996-2009. The stationary experiment was established in 1962. Founded by: Professor O. Mozheiko - Grand PhD in Agricultural sciences, Associate Professor R. Litvinyuk - PhD in Agricultural sciences. in July 1960, in order to characterize the soil cover and draw up the soil plan of the experimental field O. Kazakov, M. Laktionov, M. Litovchenko, V. Mukha and I. Shelar conducted a soil survey of the plot by laying sections and wells, what was reported in the theses of the scientific conference in May 1961. According to their analysis, the arable layer of soil contained: humus $-6.1 \%$, light hydrolysis nitrogen $-71.8 \mathrm{mg} / \mathrm{kg}$ soil, mobile phosphorus $-109.0 \mathrm{mg} / \mathrm{kg}$, mobile potassium $-271.9 \mathrm{mg} / \mathrm{kg}$. Based on field and laboratory studies, the authors conclude that the soil cover of the field of study is relatively homogeneous [14].

But intensive use of soil under crops has led to a decrease in humus content to 4.52-4.61\%, which was recorded by L. Vasilkina in the stationary experiment referred to in 1976. According to this indicator, the soil of the experimental field was attributed to the chernozem of the typical low humus soil, which contained mobile phosphorus from 81 to $125 \mathrm{mg} / \mathrm{kg}$ of soil and exchangeable potassium - 196-243 $\mathrm{mg} / \mathrm{kg}$ of soil, depending on the winter wheat precursor.

The full name of the soil of the study field was formulated as a typical chernozem deep low humus (weakly structural) heavy loam on the loess loam by D. Tikhonenko and Y. Degtyarev [16]. 
For many years, individual crops and six short rotation crop rotation alternatives were studied in the experiment with the following crop rotation: 1 - precursor to winter wheat, 2 - winter wheat, 3 - sugar beets, 4 - spring barley. The precursors of winter wheat, and accordingly the first crop rotations were: 1) fallow, 2) peas for grain, 3) rice for grain, 4) vetch-oat mix green feed, 5) soybean for green forage, and 6) corn for silage .

Soil samples for agrochemical analyzes were taken from a layer of 0-30 cm. Agrochemical analyzes were performed in accordance with conventional methods:

$\checkmark \quad$ content of light hydrolysis nitrogen - by Cornfield method, DSTU 7863-2015, in soil layers 0-15 and $15-30 \mathrm{~cm}$ before barley harvesting [17];

$\checkmark \quad$ content of mobile phosphorus compounds - by the Chirikov method, DSTU 4115-2002, in layers of soil 0-15 and 15-30 cm before harvesting barley [18];

$\checkmark \quad$ content of exchangeable potassium - by the Chirikov method, DSTU 4115-2002, in layers of soil 0-15 and 15-30 cm before harvesting of barley [18];

Research results and discussion. It is difficult to overestimate the problem of nitrogen nutrition in agriculture. Even D. Pryanishnikov noted that the amount of nitrogen in the soil is rarely sufficient for plants. A large amount of nitrogen in the soil is accumulated by leguminous crops. The activity of potato bacteria in combination with biological processes improves the nitrogen balance of the soil.

The amount of light hydrolysis nitrogen in the arable layer of typical chernozem in its determination in the last field of rotation during the eleven rotations was almost the same and ranged from $112-120 \mathrm{mg} / \mathrm{kg}$ of soil (Table), which is estimated to be low in gradation. Moreover, there is a tendency to increase its content in crop rotations with legumes of winter wheat.

Content of available nutrient forms in crop rotation with different precursors of winter wheat, $\mathrm{mg} / \mathrm{kg}$ soil (average 1996-2009)

\begin{tabular}{|c|c|c|c|c|c|c|c|}
\hline \multirow[b]{2}{*}{$\begin{array}{l}\text { Substan } \\
\text { ce }\end{array}$} & \multirow[b]{2}{*}{$\begin{array}{r}\text { Layers } \\
\text { of soil, } \mathrm{cm}\end{array}$} & \multicolumn{6}{|c|}{ The predecessor of winter wheat } \\
\hline & & fallow & peas & $\begin{array}{l}\text { lathyru } \\
\text { S }\end{array}$ & $\begin{array}{l}\text { vetch- } \\
\text { oat mix }\end{array}$ & $\begin{array}{l}\text { soybe } \\
\text { an }\end{array}$ & corn \\
\hline \multirow{3}{*}{ Nitrogen } & $0-15$ & 111 & 117 & 114 & 121 & 118 & 110 \\
\hline & $15-30$ & 114 & 116 & 117 & 119 & 120 & 113 \\
\hline & $0-30$ & 113 & 117 & 116 & 120 & 119 & 112 \\
\hline \multirow{3}{*}{$\mathrm{P}_{2} \mathrm{O}_{5}$} & $0-15$ & 141 & 135 & 126 & 137 & 121 & 124 \\
\hline & $15-30$ & 132 & 113 & 117 & 125 & 122 & 122 \\
\hline & $0-30$ & 137 & 124 & 122 & 131 & 122 & 123 \\
\hline \multirow{3}{*}{$\mathrm{K}_{2} \mathrm{O}$} & $0-15$ & 139 & 122 & 124 & 134 & 119 & 121 \\
\hline & $15-30$ & 122 & 107 & 110 & 104 & 117 & 111 \\
\hline & $0-30$ & 131 & 115 & 117 & 119 & 118 & 116 \\
\hline
\end{tabular}

In the upper soil layer $(0-15 \mathrm{~cm})$ there is a dependence of this index on rotation. A slightly higher amount of nitrogen was recorded in crop rotations with legumes, namely: with peas $-117 \mathrm{mg} / \mathrm{kg} \mathrm{soil,}$ lathyrus -114 , soybeans -118 , and its highest content was in crop rotation with occupied vetch-oat mix fallow - $121 \mathrm{mg} / \mathrm{kg}$ soil. The increase in the content of this element in the soil, in our opinion, is due to the ability of legumes to accumulate it due to nitrogen fixation in the root system and crop residues. Studies have shown a decrease in the amount of nitrogen in crop rotation with corn for silage and fallow - 110 and $111 \mathrm{mg} / \mathrm{kg}$, respectively. In our opinion, in the crop rotation with fallow, less nitrogen was produced due to the absence of root and post-harvest residues during field breeding, and in the case of corn, a considerable amount of it was used to form a large amount of vegetated alienated mass.

The content of light hydrolysis nitrogen in the soil layer $15-30 \mathrm{~cm}$ did not exceed the values of the upper $(0-15 \mathrm{~cm})$ layer, which indicates the homogeneity of soil supply with this element. Despite the fact that the bulk of the root system of crops grown in the studied crop rotations is located in the arable layer of soil, this created favorable conditions for their development, especially in versions with legumes.

Comparison of our data on the content of light hydrolysis nitrogen in short-term rotations (1996-2009) with the initial data obtained during the laying of the experiment (1960) showed that the use of these rotations and the introduction of legumes did not worsen, and even improved soil nitrogen availability.

The availability of soil with mobile phosphorus is an indicator of its state of cultivation. With a lack of it in plants, the synthesis of proteins and carbohydrates is inhibited, there is a delay in growth and development and, as a result, their productivity decreases. Adequate plant nutrition with phosphorus accelerates the formation of reproductive organs, plant development and improves product quality. Crop phosphorus stocks are affected by crops, a crop rotation system, and a fertilizer system.

According to the results of our research, there was no clear dependence of this indicator on crop rotation. In the last 14 years of studies in the last crop rotation field, the amount of mobile phosphorus in the arable layer of soil, according to the existing estimate of its content, was increased and ranged from $122-137 \mathrm{mg} / \mathrm{kg}$ of soil (see Table 1). Moreover, the highest index of its content was in rotation with fallow $-137 \mathrm{mg} / \mathrm{kg}$ of soil. 
Better soil moisture conditions in the fallow version, lack of phosphorus removal by plants in this field, higher crop yields in crop rotation and, as a consequence, a greater number of crop residues that remained in the soil - all these factors, in our opinion, contributed to a noticeable increase in mobile forms in the soil. Chernozem soils are known to be well supplied with phosphorus. In addition, a significant part of it returns to the soil with plant debris in the process of their decomposition. The variant with the vetch-oat mix was approaching the fallow one by this indicator $-131 \mathrm{mg} / \mathrm{kg}$. Vetch-oat mix before other predecessors of winter wheat frees up the field and this makes it possible to save moisture. In addition, the removal of phosphorus from the crop is reduced and the mobilization processes in the soil are improved due to the legume component, which helps to increase its content. Studies have shown a marked decrease in the content of mobile phosphorus in crop rotation, where the predecessors of winter wheat were legumes: peas, lathyru and soybeans. According to the obtained data, the amount of this element in the soil in these variants was 124,122 and $122 \mathrm{mg} / \mathrm{kg}$, respectively, due to the increased activity of microflora, which leads to its temporary fixation by microorganisms in organic form. Moreover, a large part of phosphorus imposed with harvest of crops. In crop rotation with corn for silage mobile phosphorus content amounted to $123 \mathrm{mg} / \mathrm{kg}$ soil. According to this indicator, crop rotation with corn is at the level of crop rotation with the legume component.

Studies have found an increase in the content of mobile phosphorus in the upper $(0-15 \mathrm{~cm})$ layer of soil in all crop rotations, which is due to the number of crop residues in this layer and the less intensive use of its root system of plants, which branches in the lower layer of soil. The content of mobile phosphorus retains the advantage of the fallow version over others.

Comparing the results obtained with the initial data from the stationary experiment, it should be noted that the content of mobile phosphorus in the arable layer of soil during the period of use of short-term crop rotations increased slightly.

Potassium plays an important role in crop production. It increases the winter and drought resistance of plants. Most researchers believe that its amount remains virtually unchanged depending on its predecessors. Other researchers believe that the use of fertilizers and crop rotation increases the level of supply of chernozem with potassium.

Studies have found an increase in the content of exchangeable potassium in the arable layer of soil in rotation with fallow. Its amount in the soil before barley harvest (fourth crop rotation field) was $131 \mathrm{mg} / \mathrm{kg}$ of soil, which is on average more than after other precursors of $14 \mathrm{mg} / \mathrm{kg}$ of soil. Moreover, in embodiments of precursors bean and corn for silage were almost equivalent data vary between 115-119 $\mathrm{mg} / \mathrm{kg}$ soil.

Unlike nitrogen and phosphorus, black earth soils are known to be more enriched in potassium. The conversion of exchangeable potassium to a non-exchangeable form mostly occurs after the soil has dried up. Therefore, the high content of exchangeable potassium in both the top and bottom of the fallow variant, above all, can be attributed to the higher content of moisture in it. The advantage of fallow option over other crop rotations can also be explained by the lower removal of its plants. The higher content of exchangeable potassium in the upper $(0-15 \mathrm{~cm})$ of the arable layer in all crop rotations is probably due to the greater mass of crop residues in it and the movement of potassium from the lower horizons. In general, the content of exchangeable potassium in the soil can be classified as high, but far enough from the optimal values for typical chernozem. If, before the foundation of the experiment (1960), the arable layer of soil contained $271.9 \mathrm{mg} / \mathrm{kg}$ of soil, then by the end of the 11th rotation, its amount averaged 120 $\mathrm{mg} / \mathrm{kg}$ of soil by rotation. That is, during the use of short-term crop rotations there is a decrease in the amount of potassium exchange in the soil. As for the amount of potassium in the upper and lower parts of the plow layer, we see a pattern similar to that of phosphorus.

\section{Conclusions}

The amount of light hydrolysis nitrogen in the arable layer of typical chernozem in determining it in the last field crop rotation during the eleven rotations was almost the same and ranged from 112-120 $\mathrm{mg} / \mathrm{kg}$ of soil. The tendency to increase its content in crop rotations with legumes of winter wheat predetermined.

A clear dependence of the content of available phosphorus on the alternation of crops in crop rotation was not observed. For an average of 14 years of research, the amount of mobile phosphorus in the arable soil has ranged from $122-137 \mathrm{mg} / \mathrm{kg}$ of soil. Higher indicators of its content were in rotation with fallow - $137 \mathrm{mg} / \mathrm{kg}$ and fallow occupied vetch-oat mix $-131 \mathrm{mg} / \mathrm{kg}$ of soil.

Revealed an increase in the content of exchangeable potassium in the topsoil in rotation with fallow. Its amount in soil was on average higher than that of other precursors by $14 \mathrm{mg} / \mathrm{kg}$ of soil. In variants with legume precursors and corn for silage, data were obtained that are almost equivalent, ranging from $115-119 \mathrm{mg} / \mathrm{kg}$.

\section{References}

1. Grinchenko, A. M. (1954). Vliyanie mnogoletnih trav na okulturivanie solontsovyih pochv Srednego Pridneprovya: monografiya [The influence of perennial grasses on the cultivation of solonetzic soils of the Middle Dnieper: monohrafiia]. Kiev: AN USSR. [In Russian].

2. Demchyshyn, A. M., Vishchak, V. M., \& Svita, D. Ya. (2011). Problemy vidtvorennia i pidvyshchennia rodiuchosti gruntu ornykh zemel Lvivskoi oblasti ta shliakhy yikh vyrishennia [Problems 
of reproduction and increase of soil fertility of arable land of Lviv region and ways of their solution]. Agroecological journal, 2, 58-63. [In Ukrainian].

3. Hospodarenko, H. M., Prokopchuk, I. V., \& Kryvda, Yu. I. (2015). Pokaznyky rodiuchosti chornozemu opidzolenoho pislia tryvaloho zastosuvannia dobryv u polovii sivozmini [Fertilizer fertility rates of podzol after long-term use of fertilizers in field rotation]. Bulletin of Zhytomyr National Agroecological University, 2(50), 1, 3-9. [In Ukrainian].

4. Baliuk, S. A., \& Miroshnychenko, M. M. (eds.) (2016). Systemy udobrennia silskohospodarskykh kultur u zemlerobstvi pochatku XXI stolittia [Systems of fertilization of crops in agriculture of the beginning of the XXI century]. A monograph. Kyiv: Alpha-stevia.

5. Lopushniak, V., Poliukhovych, M., \& Lahush, N. (2017). Vplyv systemy udobrennia na rodiuchist temno-sirykh opidzolenykh gruntiv ta produktyvnist kultur polovoi sivozminy zakhidnoho Lisostepu Ukrainy [Influence of fertilizer system on the fertility of dark gray podzolized soils and productivity of field crop rotation of the western forest-steppe of Ukraine]. Bulletin of the University of Lviv. Geographic Series, Issue 51, 214-223. [In Ukrainian].

6. Sulieman, S. (2015). Legume nitrogen fixation in a chan-ging environment. Springer International Publishing, Cham. doi: 10.1007/978-3-319-06212-9_3.

7. Reddy, P. P. (2016). Sustainable intensification of crop production. doi: 10.1007/978-981-10-27024.

8. Buragohain, S., Sharma, B., Nath, J. D. et al. (2017). Effect of ten years of biofertilizer use on soil quality and rice yield on an inceptisol in Assam, India. Soil Res., 56, 49-58. doi: 10.1071/SR17001.

9. Kostyichev, P. A. (1898). Pochva, ee obrabotka i udobrenie [Soil, its processing and fertilizer]. St. Petersburg: Typography of M. Stasyulevich. [In Russian].

10. Hepenko, O. V. (2010). Zmina pokaznykiv rodiuchosti chornozemu typovoho pid vplyvom ahrotekhnichnoho navantazhennia [Change in fertility indicators of typical chernozem under the influence of agro-technical load]. Bulletin of Kharkiv National Agricultural University. Series Soil Science, Agrochemistry, Agriculture, Forestry, 4, 126-129. [In Ukrainian].

11. Balaievб A. D., \& Tonkhaб O. L. (2016). Orhanichna rechovyna tsilynnykh i osvoienykh chornozemiv Lisostepu i Stepu Ukrainy [Organic matter of virgin and developed black soils of the Forest Steppe and Steppe of Ukraine]. Collection of scientific papers. Soil protection. (pp. 13-14). Kyiv. [In Ukrainian].

12. Dhakal, Y., Meena, R. S., \& Kumar, S. (2016). Effect of INM on nodulation, yield, quality and available nutrient status in soil after harvest of green gram. Legum Res., 39(4), 590-594.

13. Liu Jian, Bergkvist Goran, \& Ulen Barbro (2015). Biomass production and phosphorus retention by catch crops on clay ey soils in southern and central Sweden. Field Crops Research, 171, 130-137. doi: 10.1016/j.fcr.2014.11.013.

14. Kazakov, A. A., Laktionov, N. I., Litovchenko, N. S., Muha, V. D., \& Shelar, I. A. (1961). Harakteristika pochvennogo pokrova opyitnogo polya uchebno-opyitnogo hozyaystva "Kommunist" [Characteristics of the soil cover of the experimental field of the training and experimental farm "Communist"] Collection of scientific treatises. (Issue 1, pp. 27-29). Kharkov. [In Russian].

15. Vasilkina, L. L. (1980) Vliyanie predshestvennikov ozimoy pshenitsyi na izmenenie elementov plodorodiya tipichnogo chernozyoma. [Influence of winter wheat precursors on the change in fertility elements of a typical black soil]. Plodorodie pochv i effektivnost udobreniy: sbornik nauchnykh trudov Khark. s.-kh. in-ta im. V.V. Dokuchaeva [Soil fertility and fertilizer efficiency: collection of scientific papers of Kharkiv National Agricultural University]. (Vol. 273, pp. 23-29). [In Russian].

16. Tykhonenko, D. H., \& Dehtiarov, Yu. V. (2016). Gruntovyi pokryv doslidnoho polia "Rohanskoho statsionaru" Kharkivskoho NAU im. V. V. Dokuchaieva [Soil cover of the experimental field of "Rogan stationary field" of Kharkov NAU named after V. V. Dokuchaev]. Bulletin of Kharkiv National Agricultural University. Series Soil Science, Agrochemistry, Agriculture, Forestry, 2, 5-15. [In Ukrainian].

17. DSTU 7863-2015 Yakist gruntu. Vyznachennia lehkohidroliznoho azotu metodom Kornfilda. [Chynnyi vid 2016-07-29]. (2016). [DSTU 7863-2015 Soil quality. Determination of light hydrolysis nitrogen by the Cornfield method. [Effective from 2016-07-29]. Kyiv. [In Ukrainian].

18. DSTU 4115-2002. Yakist gruntu. Vyznachennia rukhomykh spoluk fosforu i kaliiu za modyfikovanym metodom Chyrikova. [Chynnyi vid 2003-01-01]. (2003). [DSTU 4115-2002. Soil quality. Determination of mobile phosphorus and potassium compounds by the modified Chirikov method. [Effective from 2003-01-01]. Kyiv. [In Ukrainian]. 